Jurnal Bisnis dan Manajemen, Volume 20, No. 1, March 2019, p. 3-14

\title{
GREEN LIFESTYLE AND POS: WHICH ONE DOES HAVE THE BIGGEST ROLE IN INFLUENCING THE INFLUENCE OF GREEN HRM ON EMPLOYEE PERFORMANCE?
}

\author{
Nury Ariani Wulansari ${ }^{1}$, Rini Setyo Witiastuti ${ }^{2}$, Siti Ridloah $^{3}$ \\ 1,2,3 Universitas Negeri Semarang, Indonesia
}

\begin{abstract}
This study aims to investigate the effect of Green HRM on performance, and how the correlation is moderated by Perceived Organizational Support (POS) and green lifestyle. The population of this study was employees in state universities in Central Java Province. The methods of data collection were by employing observation, interviews, and questionnaires. The sampling technique used purposive sampling technique, and the number of samples was 232 . Structural Equation Modeling (SEM) analysis by using warp PLS program was used to test the hypothesis. The study result shows that Green HRM affects employee performance. Perceived organizational support strengthens the correlation of Green HRM and organizational identification. Meanwhile, green lifestyle does not become a moderating variable in the correlation of Green HRM and employee performance. This study provides a description of the importance of Green HRM to be applied in profit or non-profit organizations. This study provides a new point of view that Green HRM has a vital role in the university context.
\end{abstract}

Keywords: Green HRM, green lifestyle, higher education, perceived organizational support, job performance

\section{GAYA HIDUP HIJAU DAN POS: MANAKAH YANG MEMILIKI PERAN TERBESAR DALAM MEMPENGARHUI PENGARUH SDM HIJAU TERHADAP KINERJA KARYAWAN?}

\begin{abstract}
ABSTRAK
Penelitian ini bertujuan untuk menyelidiki efek Green HRM pada kinerja, dan bagaimana hubungan ini dimoderasi oleh Perceived Organizational Support (POS) dan gaya hidup hijau. Populasi penelitian ini adalah karyawan di perguruan tinggi negeri di Provinsi Jawa Tengah. Metode pengumpulan data adalah dengan menggunakan observasi, wawancara, dan kuesioner. Teknik pengambilan sampel menggunakan teknik purposive sampling dan jumlah sampel adalah 232. Analisis Structural Equation Modeling (SEM) dengan menggunakan program warp PLS digunakan untuk menguji hipotesis. Hasil studi menunjukkan bahwa Green HRM mempengaruhi kinerja karyawan. Dukungan organisasi dirasakan memperkuat korelasi HRM Hijau dan identifikasi organisasi. Sementara itu, gaya hidup hijau tidak menjadi variabel moderasi dalam korelasi Green HRM dan kinerja karyawan. Studi ini memberikan deskripsi pentingnya Green HRM untuk diterapkan dalam organisasi profit atau nirlaba. Studi ini memberikan pandangan baru bahwa Green HRM memiliki peran penting dalam konteks universitas.
\end{abstract}

Kata-kata Kunci: Praktik SDM hijau, gaya hidup hijau, persepsi dukungan organisasional, kinerja, pendidikan tinggi

Korespondensi: Nury Ariani Wulansari, S.E., M.Sc. Universitas Negeri Semarang. Jln. Taman Siswa, Sekaran, Gn. Pati, Kota Semarang, Jawa Tengah 50229, Indonesia. Email: nuryariani@mail.unnes.ac.id 
Jurnal Bisnis dan Manajemen, Volume 20, No. 1, March 2019, p. 3-14

\section{INTRODUCTION}

The concept of an eco-friendly company is inseparable from human resource management that reaches out the aspect of eco-friendly. It is because the quality of human resources and human resource management strategies can affect the company's performance result (Lee et al., 2010). As a valuable business partner, human resources are part of the organizational strategy (Purwanto, 2010). The increasing popularity of initiatives to overcome proactive environmental management concerns raises the perspective of green human resources management (GHRM) practices (Siyambalapitiya et al,, 2018). GHRM has an essential role in environmental management, as human resource functions play a role in achieving the goals of an eco-friendly company (Kim et al., 2017).

In order to a company to achieve ecological sustainability, it is crucial to understand how GHRM affects employees' eco-friendly behavior, which in turn affects the company's environmental performance (Kim et al., 2017). Green HRM complements the needs of an organization by providing employees who are environmentally aware, committed, and competent (Nejati et al., 2017).

The implementation of green HRM by an organization, in fact, can affect the organization in achieving competitive advantages. Green HRM is a new concept related to employee management, which involves HRM practices (recruitment, placement, training, development, job design, information sharing practices) with eco-friendly principles. Pandey et al. (2013) stated that the implementation of green HRM by an organization could improve the performance results of its employees.

Some studies have investigated the critical role of green HRM in an organization. The studies conducted by Obaid \& Alias, (2015), Arulrajah, (2015) and (Renwick et al., 2012) showed that green HRM is a factor which can affect the performance of an organization. Green HRM implemented by the organization will give an impact on building the employees' moral that is more environmentally aware. Employees tend to react positively to green HRM practices because it can increase self-motivation (Dutton et al., 1994; Smidts et al., 2001), encourage and provide opportunities for employees to participate and engage in green activities.

The effect of green HRM on the performance is not only a direct effect. Kim et al. (2017) showed that green HRM increases employee organizational commitment and employee performance with the support of ecofriendly employee behavior (green lifestyle). Likewise, Ragas et al. (2017) showed that a green lifestyle could be a moderator in the effect of green HRM on work output. Another factor that is expected to play a role in strengthening the effect of green HRM is the support provided by the organization. The evaluation of the employee's green performance cannot be realized if the organizational support provided is too weak. It means that the control and commitment of the organization must be realized in a non-impartial policy to support the implementation of green HRM (He \& Brown, 2012; Demir, 2015). The perceived organizational support can be a moderating factor for the correlation of $\mathrm{HR}$ practices (Shen et al., 2016), employee behavior (Hur et al., 2015), and work engagement (Aktar, 2017) on the 
Jurnal Bisnis dan Manajemen, Volume 20, No. 1, March 2019, p. 3-14

work outcomes.

Research on green HRM is becoming essential for several reasons. Firstly, the implementation of green HRM is not only needed in the business or company field, but also the realm of educational organizations. This is because green HRM which is an element of corporate social responsibility (CSR) and the Environmental Management System is also critical to be considered by Educational Institutions, especially universities (Shen et al., 2016). The "green" value implemented will increase CSR commitment and the university image. This is supported by Baried et al. (2012) and Subagyo (2014) stating that CSR and the Environmental Management System are the embodiments of commitments built by universities to contribute for improving the community environmental welfare and the universities image. Cherian and Jacob (2012) revealed that there were still gaps in the empirical research results of green HRM in the world of business and education.

Secondly, besides the gaps, the research conducted by Ragas et al. (2017) showed that in reviewing green HRM, it is necessary to consider its characteristics or personality. The more a person has a personality or lifestyle that is committed to the environment, the more effective the green HRM will be. The study conducted by Ragas et al. (2017) showed that a green lifestyle could be a moderator green HRM effect on work output. Besides being moderated by the green lifestyle, this study also attempts to investigate whether employee perceptions towards organizational support can strengthen the correlation of green HRM and performance. For example, the study results of Shen et al. (2016), Hur et al. (2015), and Aktar (2017) showing that the perceived organizational support is a moderating explanatory in work outcomes. Thirdly, based on research Siyambalapitiya et al. (2018), there is still debate and uncertainty about the needed GHRM practices to improve environmental performance in developing countries.

\section{LITERATURE REVIEW}

\section{Green Human Resource Management (HRM)}

Human Resource Management (HRM) is defined as a system that contains a set of activities, functions, and processes that direct the development and maintenance of a company's human resources (Cherian \& Jacob, 2012). Some experts relate HRM to environmental management and name it green HRM (Kim et al., 2017). Particular procedure to implement green HRM practices according to Chen \& Boiral (2013) is a fourstep model for environmental HRM: (1) providing environmental vision as a guide, (2) training employees to share the vision and goals of their environment, (3) evaluating the environmental performance of employees, and (4) acknowledging the environmental activities of employees using rewards program. To implement an effective green human resource management, it is necessary to improve technical and management skills related to the green concept for all company members. Therefore, the company will look for appropriate innovations and management techniques that provide a significant sustainable impact on the company so that it can become a competitive advantage (Cherian \& Jacob, 2012).

To develop a company framework that fits the 
Jurnal Bisnis dan Manajemen, Volume 20, No. 1, March 2019, p. 3-14

green management target, an effective HR management system is also needed, starting from the employee recruitment strategy, compensation system, rewards and evaluation process which includes the points for environmental conservation awareness, as well as environmental training and development programs. According to Cherian \& Jacob (2012), the higher the effect of green human resource policies, the higher the company's adaptability in implementing the determined environmental management systems will be.

The importance of a good green HRM implementation affects the development of employees' morale, which will help in achieving benefits for both employees and the company. Employees who are active in environmental management activities will make a good contribution to the implementation of company's green environment strategy to create more significant opportunities for the emergence of improvisation and innovation related to more conservation organizational activities. It will create green products, and the benefits of cost savings in organizational activities will even increase stakeholders' satisfaction in certain situations and conditions. Nowadays, stakeholders' paradigm has tended to the companies which implement good environmental standards so that the application of green HRM policies can be a separate strategy for achieving competitive advantage in today's business world (Cherian \& Jacob, 2012).

GHRM is related to the development of green abilities in recruiting, selecting, training, and developing green leadership. GHRM handles employees green motivation by evaluating and valuing employees green performance. GHRM deals with creating employee engagement by empowering them and producing an eco-friendly organizational culture (Kim et al., 2017).

\section{Perceived Organizational Support (POS)}

Employee behavior in the organization is not only affected by job satisfaction but also by other factors, including the Perceived Organizational Support towards him. Eisenbergeret et al. (1986), in this case, defined Perceived Organizational Support as employees' global beliefs about the extent to which an organization care about their welfare and value their contributions. The global belief in question is the consistency of employees regarding various evaluations from the organization that may be given to them and various actions that can be done by the organization both beneficial and detrimental for them. Perceived organizational support is the central concept of organizational support theories (Eisenberger et al., 1986; Rhoades \& Eisenberger, 2002; Ramadoss \& Lape, 2014).

Organizational support theory elaborates that in order to meet socio-emotional needs and to assess the benefits of increasing business during the work, employees build a general perception of the extent to which the organization values their contribution and cares for their welfare (perceived organizational support). Employees' care for the organization and the achievement of the organization's goals can be shown by presenting positive attitudes and work behaviors that are in line with what is expected by the organization (Haryokusumo, 2015). 
Jurnal Bisnis dan Manajemen, Volume 20, No. 1, March 2019, p. 3-14

\section{Employee Performance}

Basically, an employee in accomplishing the tasks assigned to her/him is expected to show the best performance that can be demonstrated by the employee, besides, the performance demonstrated by the employee is definitely affected by various essential factors for the improvement of the work outcomes that become the goals of the organization or institution where the employee works (Rivai, 2005). This performance needs to be measured by the leader so that the development of employee performance in particular and organization performance, in general, can be investigated. Performance is the work results in their quality and quantity achieved by an employee in accomplishing the tasks based on the responsibilities given (Dirisu et al., 2018) (Ng \& Feldman, 2013). Employee performance is the willingness of a person or group of people to do an activity and perfect them according to their responsibilities with the expected results (Sahin et al., 2015; Ronen \& Zuroff, 2017).

In this study, employee performance will be more viewed explicitly from their "green" performance. The green performance takes the definition of performance in general, then being developed to adjust Green HRM as its management strategy. Green performance is proposed by Opatha and Arulrajah (2014), which looks at the concept of performance from a "green" point of view as to the extent to which employees engage in the behavior (actions and activities) and produce the performance that conforms to green values (conservative) during a certain period. This is interesting, considering that green HRM is closely related to the implementation or practices of Human
Resource, which is considered "eco-friendly" or "conservative." Hence, it is crucial to see, to what extent green HRM practices can affect the employee performance who have "green" values.

\section{Hypothesis}

Green HRM is a managerial implication that can affect the level of more positive work behavior, such as high performance (Shen et al., 2016). This shows that green HRM is an essential factor in improving employee performance. The effect of green HRM on performance seems to be strengthened by several factors. Employee attitude and behavior, such as an eco-friendly or green lifestyle role in strengthening the effect of green HRM (Kim et al., 2017; Ragas et al., 2017). Meanwhile, based on the studies by Shen et al., (2016), Hur et al., (2015), and Aktar (2017) that the perceived organizational support is an explanatory moderator factor on work outcomes.

Therefore, green HRM can directly affect employee performance. However, the correlation of green HRM and performance can be strengthened by perceived organizational support felt by both by the employees and employee attitudes that tend to be a green lifestyle.

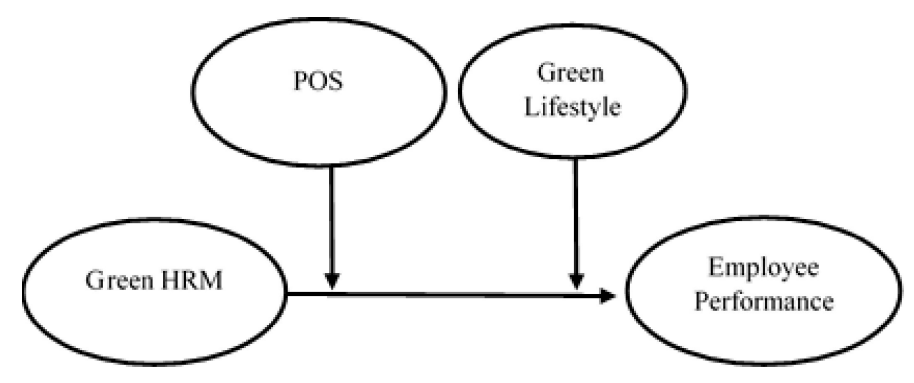

Figure 1. Research Model

Based on the framework, the hypotheses are 
Jurnal Bisnis dan Manajemen, Volume 20, No. 1, March 2019, p. 3-14

arranged as follows:

H1: Green HRM has a positive effect on performance $\mathrm{H} 2$ : The correlation of green HRM on performance will be moderated by perceived organizational support.

H3: The correlation of green HRM on performance will be moderated by a green lifestyle.

\section{METHODS}

\section{Research Design and Population}

This research design employed a quantitative approach. The data sources on quantitative studies were obtained from primary data sources. This study aims to examine the effect of green HRM on employee performance moderated by perceived organizational support and green lifestyle. The population of this study was the employees of 6 (six) state universities in Central Java province with a total of 232 employees.

Meanwhile, the sampling technique employed in this study was purposive sampling, where the sample was selected based on certain considerations. The sample consideration that was selected was the respondent (employees) who has 5-year work experience. The consideration was based on the assumption that employees with 5-year work experience can identify the organization. The number of the sample obtained in this study was 232 respondents. The variables in this study include Green Human Resources Management, Perceived Organizational Support, Green Lifestyle, and Employee Performance.

Green HRM was measured by using the instrument adopted from Ragas et al. (2017), including organizational practices that support the environment.
Perceived organizational support was measured by using the instruments adopted from the Survey of Perceived Organizational Support Eisenberger et al. (1986), which includes perceptions of caring, attention, and support provided by an organization. Employee performance was measured by adopting the instrument from Ragas et al. (2017), which includes task competency, flexibility and efficiency, professional development, and work efficiency. Likewise, the Green lifestyle variable was measured by adopting the instrument from Ragas et al. (2017), which includes eco-friendly behavior in daily life.

Analysis of Structural Equation Modeling (SEM) with warp PLS program was used to test hypotheses. This statistical analysis tool was selected as it has several advantages. First, SEM-PLS is suitable for the research models that used latent variables and calculated measurement error. Second, SEM analysis can simultaneously test multiple dependence as in this research model. Third, component-based SEM (PLS) can estimate a quite complex model with small sample size.

\section{RESULTS AND DISCUSSION}

\section{Instrument Test (validity test and reliability test)}

This study used convergent validity and discriminant validity. Below is the explanation of convergent validity and discriminant validity:

The result of convergent validity test on the variable statement items in this study indicates that all statements fulfill the convergent validity because the factor load $\geq$ 0.30 so that the statement can be used in this study. Meanwhile, the result of discriminant validity test can be 
Jurnal Bisnis dan Manajemen, Volume 20, No. 1, March 2019, p. 3-14

seen in table 1 below:

Table 1. AVE Square Root and Correlation

Coefficient

\begin{tabular}{ccccc}
\hline & GHRM & EP & POS & GL \\
\hline GHRM & $\mathbf{0 . 6 7 6}$ & 0.461 & 0.495 & 0.631 \\
EP & 0.461 & $\mathbf{0 . 6 8 8}$ & 0.301 & 0.334 \\
POS & 0.495 & 0.301 & $\mathbf{0 . 8 3 2}$ & 0.450 \\
GL & 0.631 & 0.334 & 0.450 & $\mathbf{0 . 6 3 4}$ \\
\hline
\end{tabular}

Source: Processed Primary Data (2018)

The result of AVE square root test and Correlation Coefficient shows that all statement items of green human resource management, perceived organizational support, green lifestyle and employee performance are greater than the correlation of the variables concerned. So, the discriminant validity is fulfilled, meaning that all statements can represent problems of the study and correspond with the real conditions of the research object.

\section{Result of Reliability Test}

Below is the result of the instrument reliability test:

Table 2. Composite Reliability and Cronbach's Alpha

\begin{tabular}{cccc}
\hline No. & Variable & $\begin{array}{c}\text { Composite } \\
\text { Reliability } \\
\text { Coefficient }\end{array}$ & $\begin{array}{c}\text { Cronbach's } \\
\text { Alpha } \\
\text { Coefficient }\end{array}$ \\
\hline 1 & GHRM & 0.880 & 0.845 \\
2 & POS & 0.953 & 0.944 \\
3 & GL & 0.768 & 0.622 \\
4 & EL & 0.925 & 0.913 \\
\hline
\end{tabular}

Source: Processed Primary Data (2018)

The result of reliability test on the research variables shows that all variables fulfill the composite reliability because the composite reliability coefficients $>0.70$ and all variables also fulfill the internal reliability consistency because Cronbach's alpha coefficients > 0.60 so that all variables fulfill composite reliability and internal consistency. It means that all statements of green human resources management, perceived organizational support, green lifestyle, and employee performance can measure a problem with regularly so that it can be considered as a reliable tool.

\section{The Result of Descriptive Analysis Test}

Below is the result of descriptive analysis test:

Table 3. Descriptive Result

\begin{tabular}{ccc}
\hline No. & Variable & Mean \\
\hline 1. & GHRM & 40.22 \\
2. & EP & 55.57 \\
3. & POS & 32.30 \\
4. & GL & 23.81 \\
\hline
\end{tabular}

Source: Processed Primary Data (2018)

Based on table 3, it can be seen that the mean of respondents' answers is in the different categories. If it is viewed from the greatest mean sequence of variables perceived by respondents, we can see the first one is the employee performance variable (55.57), GHRM (40.22), perceived organizational support (32.30), green lifestyle (23.81). Thus, the variable which is the best perceived by respondents are employee performance, and the worst perceived by respondents is green lifestyle.

\section{Model Fit and Quality Indices}

The criteria included in the goodness of fit model in Table 3 is as the rule of thumb, so that the test results should not be applied rigidly and absolutely. When there are one or two indicators of model fit and quality indices, the model can still be used. The test results are in the 
Jurnal Bisnis dan Manajemen, Volume 20, No. 1, March 2019, p. 3-14

table 4 below:

Table 4. Model Fit and Quality Indices

\begin{tabular}{|c|c|c|c|c|}
\hline No. & $\begin{array}{c}\text { Model Fit } \\
\text { and Quality } \\
\text { Indices }\end{array}$ & $\begin{array}{c}\text { Fit } \\
\text { Criteria }\end{array}$ & $\begin{array}{c}\text { Analysis } \\
\text { Result }\end{array}$ & Desc. \\
\hline 1. & $\begin{array}{c}\text { Average } \\
\text { path } \\
\text { coefficient } \\
\text { (APC) }\end{array}$ & $\mathrm{p}<0.05$ & $\begin{array}{c}0.238 \\
(\mathrm{P}<0.001)\end{array}$ & Good \\
\hline 2. & $\begin{array}{l}\text { Average } R \text { - } \\
\text { squared } \\
\text { (ARS) }\end{array}$ & $\mathrm{p}<0.05$ & $\begin{array}{c}0.253 \\
(\mathrm{P}<0.001)\end{array}$ & Good \\
\hline 3. & $\begin{array}{l}\text { Average } \\
\text { adjusted R- } \\
\text { squared } \\
\text { (AARS) }\end{array}$ & $\mathrm{p}<0.05$ & $\begin{array}{c}0.243 \\
(\mathrm{P}<0.001)\end{array}$ & Good \\
\hline 4. & $\begin{array}{c}\text { Average } \\
\text { block VIF } \\
\text { (AVIF) }\end{array}$ & $\begin{array}{c}\text { Accepted } \\
\text { if }<=5 \text {, } \\
\text { Ideally }< \\
=3.2\end{array}$ & 1.044 & Ideal \\
\hline 5. & $\begin{array}{c}\text { Average full } \\
\text { collinearity } \\
\text { VIF } \\
\text { (AFVIF) }\end{array}$ & $\begin{array}{c}\text { Accepted } \\
\text { if }<=5, \\
\text { Ideally }< \\
=3.2\end{array}$ & 1.826 & Ideal \\
\hline 6. & $\begin{array}{l}\text { Tenenhaus } \\
\text { GoF (GoF) }\end{array}$ & $\begin{array}{c}\text { Small }> \\
=0.1, \\
\text { medium } \\
>=0.25, \\
\text { large }>= \\
0.36\end{array}$ & 0.337 & Ideal \\
\hline 7. & $\begin{array}{l}\text { Sympson's } \\
\text { paradox } \\
\text { ratio (SPR) }\end{array}$ & $\begin{array}{c}\text { Accepted } \\
\text { if }>= \\
0.7 \\
\text { Ideally } 1\end{array}$ & 1.000 & Ideal \\
\hline 8. & $\begin{array}{l}R \text {-squared } \\
\text { contribution } \\
\text { ratio } \\
\text { (RSCR) }\end{array}$ & $\begin{array}{c}\text { Accepted } \\
\text { if }>= \\
0.9 \\
\text { Ideally } 1\end{array}$ & 1.000 & Ideal \\
\hline 9. & $\begin{array}{l}\text { Statistical } \\
\text { suppression } \\
\text { ratio }(\mathrm{SSR})\end{array}$ & $\begin{array}{l}\text { Accepted } \\
\text { if }>=0.7\end{array}$ & 0.667 & Ideal \\
\hline 10. & $\begin{array}{c}\text { Nonlinear } \\
\text { bivariate } \\
\text { causallity } \\
\text { direction } \\
\text { ratio } \\
\text { (NLBCDR) }\end{array}$ & $\begin{array}{l}\text { Accepted } \\
\text { if }>=0.7\end{array}$ & 0.333 & Good \\
\hline
\end{tabular}

Source: Processed Primary Data (2018)

It can be seen from the table above that the goodness of fit model has good results to explain the correlation of latent variables and their assumptions.

\section{Direct Hypothesis Testing Result}

The hypothesis testing uses resampling method and ttest. The rules of decision for testing hypotheses are as follows: when p-value $\leq 0.10$ (alpha $10 \%$ ), it is said to be low significant or not significant so the hypothesis is rejected, if p-value $\leq 0.05$ (alpha 5\%) then it is said to be significant and if $p$-value $\leq 0.01$ (alpha $1 \%$ ) then it is said to be highly significant. Significant or highly significant both cause the hypothesis to be accepted. The result of the direct effect of hypothesis testing is such as in table 5 as follows:

Table 5. Result of Direct Effect of Hypothesis Testing

\begin{tabular}{|c|c|c|c|c|}
\hline No & $\begin{array}{c}\text { Correlation } \\
\text { among } \\
\text { Variables }\end{array}$ & Coef. & $\begin{array}{c}\text { P- } \\
\text { Value }\end{array}$ & Desc. \\
\hline 1. & $\begin{array}{c}\text { GHR } \\
\text { M }\end{array}$ & $0.483^{* *}$ & $<0.001$ & $\begin{array}{c}\text { Highly } \\
\text { Significant }\end{array}$ \\
\hline
\end{tabular}

Source: Processed Primary Data (2018)

\section{The Result of Hypothesis Testing of Moderation}

The result of the hypothesis testing of moderation is as follows:

Table 6. Result of Hypothesis Testing of Moderation

\begin{tabular}{cccccc}
\hline \multicolumn{2}{c}{ Correlation among } \\
Variables \\
$\mathrm{X}$ & Mod & Y & $\begin{array}{c}\text { Mod } \\
\text { Coef. }\end{array}$ & $\begin{array}{c}\text { P- } \\
\text { Value }\end{array}$ & Desc. \\
\hline GHRM & POS & P & 0.139 & 0.016 & Significant \\
GHRM & GL & P & -0.075 & 0.079 & $\begin{array}{c}\text { Not } \\
\text { Significant }\end{array}$ \\
\hline
\end{tabular}

Source: Processed Primary Data (2018) 
Jurnal Bisnis dan Manajemen, Volume 20, No. 1, March 2019, p. 3-14

\section{The Effect of Green HRM on Employee Performance}

Based on the result of the hypothesis testing of the direct effect, the effect of green HRM on employee performance with the path coefficient 0.483 and $p$ $<0.001$. Given that $p \leq 0.01$ then it is said to be highly significant, so $\mathrm{H} 1$ is accepted. The positive path coefficient indicates that the higher the effect of green HRM is, the more the employee performance is increasing. This is supported by the research conducted by (Obaid \& Alias, 2015), (Arulrajah, 2015), (Masri \& Jaaron, 2017), and (Renwick et al., 2012) showing that green HRM is a factor that can affect the performance of an organization. Based on this, the performance shown by employees will increase as green HRM increases.

Based on the result of descriptive analysis, GHRM (40.22) and employee performance (55.57). The high GHRM practices perceived by respondents proved to be able to improve their task competency, flexibility and efficiency, professional development, and work efficiency. For organizations, implementing green HRM will affect the building of employees' moral that is more in environmental awareness.

\section{The Moderation Effect of Perceived Organizational Support on the Effect of Green HRM on Employee Performance}

Based on the table of moderation hypothesis testing result, the moderating effect of perceived of organizational support of green HRM on the performance with the path coefficient 0.139 and $\mathrm{p}=$ 0.016 , so $\mathrm{H} 2$ is accepted. It means that the perceived organizational support can moderate because it is proven to strengthen the correlation of green HRM on performance. This is in line with the opinion that suggests that employee work output cannot be realized if the organizational support provided is too weak. It means that the control and commitment of the organization must be realized in a non-impartial policy to support the implementation of green HRM (He \& Brown, 2012).

Based on the descriptive analysis, the respondents' perceptions towards employee performance (55.57), GHRM (40.22), and perceived organizational support (32.30). In this study, the high perception of caring, attention, and support provided by the organization can strengthen the positive effect of green HRM on performance. The better employee perceptions towards organizational support, the more the positive correlation of GHRM and their task competency, flexibility and efficiency, professional development, and work efficiency will be strengthened. The results of this study are in line with the studies by Shen et al. (2016), Hur et al. (2015), and Aktar (2017) that the perceived organizational support is a moderating explanatory factor on work outcomes. In this study, the explanatory factor is green HRM, it is proven that green HRM affects performance moderated by perceived organizational support.

\section{The Moderating Effect of Green Lifestyle on the Effect of Green HRM on Employee Performance}

Based on the results of the moderation hypothesis testing, the moderating effect of green lifestyle of green HRM on employee performance with the path coefficients of -0.075 and $p=0.079$, so that $\mathrm{H} 3$ is rejected. It means that green lifestyle cannot moderate as it does not strengthen or weaken the correlation of green 
Jurnal Bisnis dan Manajemen, Volume 20, No. 1, March 2019, p. 3-14

HRM on employee performance. This is contrary to the opinion of Ragas et al. (2017) suggesting that the relationship of Green HRM and its output will be moderated by how the employee's lifestyle was.

In this study, the green lifestyle cannot strengthen or weaken the positive effect of green HRM on employee performance. Some things that may be the reasons are because the respondents' perceptions towards green HRM is higher (40.22) than the green lifestyle (23.81). Therefore, the effect of moderating (strengthening) green lifestyle does not significantly play a role (because the effect of green HRM is already very strong). Another reason is that in this study, a green lifestyle has not been strongly built. As explained by Ragas et al. (2017), after GHRM practices affect the green lifestyle, then this strong green lifestyle strengthens the correlation of GHRM and employee performance.

\section{CONCLUSION}

Based on the results, green HRM affects employee performance, so it indicates that the better the green $\mathrm{HRM}$ is, the more employee performance increases. The effect of green HRM on employee performance is proven to be affected by the perceived organizational support. This means that perceived organizational support can strengthen the positive correlation of green HRM on employee performance. The results of this study provide an understanding that green HRM is a vital tool to be applied not only to profit organizations in general but also to educational institutions (universities) in particular needs to continue implementing and increasing awareness of green HRM practices to obtain a positive work outcome. Organizations can develop a variety of strategies to motivate employees to follow GHRM practices, which can give an impact on their lifestyles and ultimately can make them "green lifestyle."

This research still has limitations, such as focusing on universities in certain regions. Therefore, further research is suggested to expand the research area. Also, this study only employs a quantitative approach, so it has not been able to answer the problems that need indepth study. Furthermore, it is recommended to use the mix method approach to obtain a more in-depth description of the phenomenon.

\section{REFERENCES}

Aktar, A. (2017). The Relationship between Employee Engagement, HRM practices and Perceived Organizational Support: Evidence from Banking Employees. International Journal of Human Resource Studies 7(3), 1-22. https://doi.org/10.5296/ijhrs.v7i3.11353

Arulrajah, A. A. (2015). Green Human Resource Management Practices: A Review Literature Review on Green HRM Practices. Sri Lankan Journal of Human Resource Management 5(1), 116.

Baride, Alfi., Septriani Nisa., dan Rahman Wildan. (2012). Analisis Pengaruh Kebijakan CSR Terhadap Kesejahteraan Masyarakat Sekitar. Prosiding Seminar dan Konferensi Nasional Manajemen Bisnis.

Chen, Y., \& Boiral, O. (2013). The Impact of Human Resource Management on Environmental Performance: An Employee-Level Study. Journal of Business Ethics 121, Issue 3, pp 451-466.

Cherian, J., \& Jacob, J. (2012). A Study of Green HR Practices and Its Effective Implementation in the Organization: A Review. International Journal of Business and Management 7(21), 25-33. https://doi.org/10.5539/ijbm.v7n21p25. 
Jurnal Bisnis dan Manajemen, Volume 20, No. 1, March 2019, p. 3-14

Dai, Kailiang \& Qin, Xinyu. 2016. Perceived Oragnizational Support and Employess Engagement: Based on the research of Organizationa identification and Organizational Justice. Open Journal of Social Sciences 4 (46-57).

Demir, Kamile. 2015. The Effect of Organizational Justice and Perceived Organizational Suport on Organizational Citizenship Behavior: The Mediating Role of Organizational Identifications. Euarsian Journal of Educational Research 60 (131-148).

Dirisu, J., Worlu, R., Osibanjo, A., Salau, O., Borishade, T., Meninwa, S., \& Atolagbe, T. (2018). An integrated dataset on organisational culture, job satisfaction and performance in the hospitality industry. Data in Brief, 19, 317-321. https://doi.org/10.1016/j.dib.2018.04.137.

Dutton, J. E., Dukerich, J. M., \& Harquail, C. V. (1994). Images Organizational and Member Identification. Administrative Science Quarterly, 39, 239-263. .

Eisenberger, R., Huntington, R., Hutchison, S., \& Sowa, D. (1986). Perceived Organizational Support.Journal of Applied Psychology, 82(5), 812-820.

Haryokusumo, D. (2015). The Effect of Workplace Spirituality Dimensions on Organizational Commitment with Perceived Organizational Support as Moderating Variable. Jurnal Dinamika Manajemen. 6(2): 187-202.

He, Hongwei., dan Brown, Andrew. 2012. Organizational Identity and Organizational Identfications: A review of The Literature and Suggestions for Future Research. Tesis. University of Warwick.

Hur, Won-Moo., Su-Jin Han., Jeong-Ju Yoo., Tae Won Moon. (2015). The moderating role of perceived organizational support on the relationship between emotional labor and job-related outcomes. Management Decision, Vol. 53 Issue: 3, pp.605624.

Jiang, K., Lepak, D. P., Hu, J., \& Baer, J. C. (2012). How does human resource management influence organizational outcomes? A meta-analytic investigation of mediating mechanisms. Academy of Management Journal, 55, 1264-1294.

Kim, Y. J., Kim, W. G., Choi, H. M., \& Phetvaroon, K.
(2019). The effect of green human resource management on hotel employees' eco-friendly behavior and environmental performance. International Journal of Hospitality Management, 76, 83-93.

Lee, F., Lee, T., \& Wu, W. (2010). The relationship between human resource management practices, business strategy and firm performance : evidence from steel industry in Taiwan. The International Journal of Human Resource Management 21(9):1351-1372.

Masri, H. A., \& Jaaron, A. A. M. (2017). Assessing green human resources management practices in Palestinian manufacturing context: An empirical study. Journal of Cleaner Production. 143, 474489.

Nejati, M., Rabiei, S., \& Chiappetta Jabbour, C. J. (2017). Envisioning the invisible: Understanding the synergy between green human resource management and green supply chain management in manufacturing firms in Iran in light of the moderating effect of employees' resistance to change. Journal of Cleaner Production, 168, 163172.

Ng, T. W. H., \& Feldman, D. C. (2013). Does longer job tenure help or hinder job performance?. Journal of Vocational Behavior, 83(3), 305-314.

Obaid, T. F., \& Alias, R. B. (2015). The Impact Of Green Recruitment, Green Training And Green Learning On The Firm Performance: Conceptual Paper, International Journal of Applied Research, 1(12): 951-953.

Opatha, H. H. D. N. P., \& A. Anton Arulrajah. (2014). Green Human Resource Management: SImplifed General Reflections. International Journal Research, Vol 7 (8) 101-112.

Pandey, Suruchi., Viswanathan, V., \& Kamboj, P. 2013. Sustainable Green HRM - Importance and Factors affecting Successful Implementation in Organizations. International Journal of Research in Management and Business (ISSN: 2395-4329): Volume 2 Issue 3.

Purwanto, Budi. 2010. Manajemen Sumber Daya Manusia Berbasis Proses: Pola Pikir Baru Mengelola Sumber Daya Manusia. Jakarta: Grassindo. 
Jurnal Bisnis dan Manajemen, Volume 20, No. 1, March 2019, p. 3-14

Ragas, S. F. P., Flora, M. A. T., Lorraine J. C. C,, \& Carolyn M. C. S. 2017. Green lifestyle moderates GHRM's impact on job performance. International Journal of Productivity and Performance Management, Vol. 66 Issue: 7, pp.857-872.

Ramadoss, K., \& Lape, M. E. (2014). Supervisor Status, Health and Organizational Commitment: Mediating Role of Support and Family- friendly Policies among Information Technology Professionals in India. Journal of Business and Management Sciences, 2 (1), pp 1-9. https://doi.org/10.12691/jbms-2-1-1.

Renwick, D. W. S., Redman, T., \& Maguire, S. (2012). Green Human Resource Management: A Review and Research Agenda. International Journal of Management Reviews 15(1).

Rhoades, L., \& Eisenberger, R. (2002). Perceived Organizational Support: A Review of the Literature. Journal of Applied Psychology, 87(4), 698-714.

Ronen, S., \& Zuroff, D. C. (2017). How does secure attachment affect job performance and job promotion? The role of social-rank behaviors. Journal of Vocational Behavior, 100, 137-148.

Sahin, F., Koksal, O., \& Ucak, H. (2015). Measuring the Relationship between Managerial Resourcefulness and Job Performance. Procedia Economics and Finance, 23(October 2014), 878-884.

Shen, J., Dumont, J., \& Deng, X. (2016). Employees ' Perceptions of Green HRM and Non- Green Employee Work Outcomes: The Social Identity and Stakeholder Perspectives. Group \& Organization Management, Vol 43, Issue 4.

Siyambalapitiya, J., Zhang, X., \& Liu, X. (2018). Green Human Resource Management: A Proposed Model in the Context of Sri Lanka's Tourism Industry. Journal of Cleaner Production, 201(02), 542-555.

Shore, L. M. \& Shore, T.H. (1995). Perceived organizational support and organizational justice. In R. Cropanzo and K.M. Kacmar (eds.) Organizational Politics, Justice, and Support: Managing social climate at work, pp. 149-1 64. Quorum Press.

Smidts, A., Pruyn, A. T. H., \& Van Riel, C. B. M. (2001). The impact of employee communication and perceived external prestige on organizational identification. Academy of Management Journal, 44, 1051-1062.

Rivai, Veithzal (2005). Manajemen Sumber Daya Manusia. Raja Grafindo Persada, Jakarta.

Wang, W., He., Zhu., dan Harris. 2015. Service workers job performance: The role of personality traits, organizational identifications, and customer orientation. Europan Journal of Marketing, Vol. 49 Issue: 11/12, pp.1751-1776. 